\title{
Incidence of pulmonary artery complications after flo watch pulmonary artery banding - CORRIGENDUM
}

A. Shauq, J. Lim, A. Narayanan, G. Gladman, I. Peart, R. A. Johnson, N. Alphonso, P. Venugopal, A. Corno, E. J. Ladusans

Received: 27 March 2011; Accepted: 2 May 2011; First published online: 23 June 2011

doi: 10.1017/S104795111100028X, Published by Cambridge University Press, 5 May 2011.

A. Shauq apologises for inclusion in the above Abstract ${ }^{1}$ author details of A. Corno. A. Corno wishes to make clear that he was included without his knowledge or consent, and does not support the content or message of the Abstract.

The Correct authorship and affiliation should have read:

Shauq A., Lim J., Narayanan A., Gladman G., Peart I., Johnson R. A., Alphonso N., Venugopal P., Ladusans E. J.

\section{Reference}

1. Shauq A, Lim J, Narayanan A, et al. Incidence of pulmonary artery complications after flo watch pulmonary artery banding. Cardiol Young 2011; 21(S1): S95-S96. 